Зухрабов Мирзабек Гашимович, $\partial-p$ вет. наук, проф., зав. кафедрой «Терапия и клиническая диагностика», ФГБОУ ВО Дагестанский ГАУ. Россия.
367032, г. Махачкала, ул. М. Гаджиева, 180.

Тел.: (8722) 68-24-68.

Ключевые слова: корова; рацион; молозиво; молоко; кальций; фосфор; микроэлементы.

\title{
THE IMPACT OF THE BALANCED FEEDING OF COWS IN THE DRY PERIOD ON THE CONTENT OF MACRO- AND MICROELEMENTS IN COLOSTRUM AND MILK
}

Krupin Evgeniy Olegovich, Candidate od Veterinarian Sciences, Leading Researcher, Head of the Department, Tatar Research Institute of Agriculture - Subdivision of the Fed-eral Research Center "Kazan Scientific Center of Russian Academy of Sciences". Russia.

Shakirov Shamil Kasimovicn, Doctor of Agricultural Sciences, Professor, Chief Re-searcher, Tatar Research Institute of Agriculture Subdivision of the Federal Research Center "Kazan Scientific Center of Russian Academy of Sciences". Russia.

Zuhrabov Mirzabek Gashimovich, Doctor of Veterinary Sciences, Professor, Head of the chair "Therapy and Clinical Diagnostics", Federal State Budgetary Educational Institution of Higher Education "Dagestan State Agricultural University named after M.M. Dzhambulatov". Russia.

Keywords: cow; diet; colostrum; milk; calcium; phosphorus; microelements

The article presents the results of the evaluation of the $d y$ namics of microelements in the colostrum and milk, as well as microelements in milk of dairy cows when used in the composition of the rations they are feeding regulators of metabolism (vitamin-mineral premixes $P 60-3 / 2$ and $P 60-3 / P$, propylene glycol, calcium salts of fatty acids) in accordance with the developed scheme of combined use. Less pronounced decrease of calcium and phosphorus content in milk of animals of the second and third groups is established. On day 30 lactation revealed a significant increase in the content of copper and selenium in indi-viduals of the second (respectively $66.2 \%(P<0.01)$ and 65.2\% $(P<0.05)$ ) and third (respectively 67.2\% $(P<0.001)$ and $73.0 \%(P<0.01))$ groups. On the 60th day of lactation in animals of the first group the increase of zinc content in milk was significant and amounted to $6.9 \%(P<0.05)$. In cows of the second and third groups, the copper content was significantly higher than in animals of the first group by $60.3 \%(P<0.01)$ and $62.6 \%(P<0.01)$, respectively. In individuals of the third group the content of selenium was significantly higher than in animals of the control group by $94.2 \%(P<0.01)$.

\section{ВОЗДЕЙСТВИЕ ЭКСТРАКТА ИЗ КОРЫ ДУБА (QUERCUS CORTEX) НА РОСТ И РАЗВИТИЕ КАРПА}

\author{
МИРОШНИКОВА Елена Петровна, Оренбургский государственный университет \\ АРИНЖАНОВ Азамат Ерсаинович, Оренбургский государственный университет \\ КИЛЯКОВА Юлия Владимировна, Оренбургский государственный университет \\ ДУСКАЕВ Галимжан Калиханович, Федеральный научный центр биологических систем \\ и агротехнологий РАН
}

МИРОШНИКОВА Мария Сергеевна, Оренбургсий государственный университет

Определено влияние экстракта из коры дуба (Quеrсиs cortex), скармливаемого в различных дозировках, на рост и развитие карпа в сравнении с пробиотиками (Вifidobacterium longuт) и антибиотиками (ципрофлоксацина гидрохлорид). Установлено повышение роста рыб на фоне введения в рацион экстрактов Quеrсиs cortex концентрацией 1 и 2 мг/кг корма на 7,9 и 10,7 \% $(P<0,05)$ соответственно. Включение в рацион пробиотика и антибиотика не показало достоверных различий по сравнению с контрольной группой.

Введение. В настоящее время при выращивании рыб и сельскохозяйственных животных для лечения различных болезней, а также для профилактики и стимуляции роста широко используют антибиотики. Установлено, что под действием большинства антибиотиков активизируются защитные силы организма. Однако при длительном применении в кормлении животных снижается их рост, резистентность; антибиотики могут накапливаться в продуктах питания, полученных от таких животных [4].

В области кормления сельскохозяйственных животных и рыб активно исследуют возмож- ность использования растительных экстрактов (фитобиотиков) и органических соединений в качестве кормовых добавок и заменителей антибиотиков $[1,2,5]$. Интерес к соединениям растительного происхождения связан с эффективной способностью фитобиотиков подавлять (ингибировать) систему Quorum Sensing (QS) бактериальных патогенов [11].

Одним из таких фитобиотиков является кора дуба (Quercus robur), содержащая не менее $8 \%$ дубильных веществ, эллаговую и галловую кислоты, кверцетин и другие биологически активные вещества [8]. 
Quercus robur показывает наиболее стабильную анти-QS активность в отсутствии явных антибактериальных эффектов. В экстракте коры дуба были определены 7 компонентов с анти-QS активностью: антиарол, ванилин, кумарин, конифериловый спирт, пирогаллол, пропилрезорцин, скополетин $[3,8]$.

В настоящее время поиск альтернативных противомикробных веществ с профилактическим и ростостимулирующим действием относится к актуальным направлениям, согласующимся со «Стратегией предупреждения распространения антимикробной резистентности в Российской Федерации на период до 2030 года», утвержденной Правительством Российской Федерации (распоряжение № 2045-р от 25.09.2017 г.).

Целью исследований было изучение влияния различных доз биологически активных веществ экстракта из коры дуба (Quercus cortex) на рост и развитие рыб в сравнении с пробиотиками и антибиотиками.

Методика исследований. Исследования проводили в условиях аквариумного стенда кафедры «Биотехнологии животного сырья и аквакультуры» Оренбургского государственного университета. Объектом исследований являлись годовики карпа, выращенные в условиях ООО «Оренбургский осетр» (г. Оренбург). Методом пар-аналогов были сформированы 6 групп $(n=20)$. После подготовительного периода (7 суток) особей переводили на условия учетного периода (35 суток). Контрольная группа получала основной рацион (ОР), I опытная - OP + экстракт Quercus cortex (1 мг/кг корма), II опытная OP + экстракт Quercus cortex (2 мг/кг корма), III опытная - OP + экстракт Quercus cortex (3 мг/кг корма), IV опытная - OP + пробиотический препарат соя-бифидум (0,7 мл/кг корма), V опытная $\mathrm{OP}$ + антибиотик ципрофлоксацина гидрохлорид (100 мг/кг корма).

Основной рацион включал в себя корм КРК-110-1 производства ОАО «Оренбургский комбикормовый завод» (г. Оренбург). Пробиотический препарат соя-бифидум (свидетельство госрегистрации RU.77.99.11.003. Е.000449.01.12 от 13.01.12) производства ООО «НПФ «Экобиос» (г. Оренбург) содержит не менее $10^{9}$ клеток Bifidobacterium longum. В качестве антибиотика использовали препарат «Антибак 250», который в качестве действующего вещества содержит ципрофлоксацина гидрохлорид.

В исследовании была использована смесь веществ, выделенных из экстракта Quercus cortex, и синтезированных химическим путем: 4-гидрокси-3-метоксибензальдегида (ванилин), 4-пропил-1,3-бензолдиол (пропилрезорцин), 4-(3-гидрокси-1-пропенил)-2-метоксифенол (конифериловый спирт), 7-гидрокси-6-метокси-2Н-1-бензопиран-2-он (кумарин), 2Н-1-бензопиранон-2 (скополетин), 3,4,5-триметилгидросифенол (антиарол).

В ходе эксперимента суточную норму кормления определяли в количестве $3 \%$ от массы рыб. Кормление подопытной рыбы осуществляли 3 раза в сутки. Живую массу контролировали еженедельно путем индивидуального взвешивания утром, до кормления $( \pm 1$ г).

Статистическую обработку полученных данных проводили с использованием программного пакета Statistica 10.0 (Stat Soft Inc., США). Проверку соответствия полученных данных нормальному закону распределения определяли при помощи критерия Колмогорова.

Результаты исследований. В ходе исследований отклонений от нормы по поведению и внешним признакам у рыб обнаружено не было. Сохранность их во всех группах составила $100 \%$. Включение в рацион карпа экстракта Quercus cortex, пробиотика и антибиотика отразилось на его росте и развитии (табл. 1). На первой неделе эксперимента достоверных различий между группами зафиксировано не было. На второй неделе в опытных группах наблюдали повышение массы рыбы по сравнению с контролем при добавлении экстракта Quercus cortex: в I группе - на $11 \%$, во II - на 12,3 \% и в III - на $10 \%$; в группах с включением в рацион пробиотика и антибиотика - на 3,9 \%. На третьей неделе динамика изменения массы рыб сохранилась, при этом наилучшие показатели были зафиксированы в группах с добавлением экстракта Quercus cortex. B I группе наблюдали повышение массы на 10,6 \%, во II - на $12,6 \%(P<0,05)$ и в III - на 8 \% по сравнению с контролем.

На 4-й и 5-й неделе эксперимента наилучшие показатели были зафиксированы в группах

Таблица 1

Динамика массы карпа

\begin{tabular}{|l|c|c|c|c|c|c|}
\hline \multirow{2}{*}{$\begin{array}{c}\text { Учетный } \\
\text { период }\end{array}$} & \multicolumn{5}{|c|}{ Группа } \\
\cline { 2 - 7 } & контроль & I & II & III & IV & V \\
\hline Начало опыта & $37,7 \pm 1,6$ & $37,8 \pm 2,0$ & $37,8 \pm 2,1$ & $37,6 \pm 1,6$ & $37,8 \pm 2,1$ & $37,6 \pm 1,7$ \\
\hline 1-я неделя & $43,6 \pm 2,0$ & $44,5 \pm 2,2$ & $47,4 \pm 3,3$ & $45,7 \pm 2,5$ & $43,9 \pm 2,0$ & $43,7 \pm 2,1$ \\
\hline 2-я неделя & $48,9 \pm 3,1$ & $54,3 \pm 3,3$ & $54,9 \pm 3,6$ & $54,0 \pm 2,7$ & $50,8 \pm 2,4$ & $50,8 \pm 2,2$ \\
\hline 3-я неделя & $54,7 \pm 3,0$ & $60,5 \pm 2,7$ & $61,6 \pm 3,0^{*}$ & $59,1 \pm 2,6$ & $55,9 \pm 2,7$ & $55,7 \pm 2,5$ \\
\hline 4-я неделя & $63,8 \pm 3,2$ & $70,2 \pm 3,0$ & $72,4 \pm 2,8^{*}$ & $63,8 \pm 3,0$ & $64,0 \pm 2,8$ & $63,6 \pm 2,7$ \\
\hline 5-я неделя & $74,9 \pm 3,5$ & $80,8 \pm 3,0$ & $82,9 \pm 3,3^{*}$ & $75,0 \pm 3,2$ & $74,5 \pm 3,0$ & $72,3 \pm 2,9$ \\
\hline
\end{tabular}

* $\mathrm{P}<0,05$ (здесь и далее). 
с добавлением экстракта Quercus cortex в концентрации 1 и 2 мг/кг корма. Констатировали повышение массы карпа на 10; 13,5 \% $(\mathrm{P}<0,05)$ и на 7,$9 ; 10,7 \%(\mathrm{P}<0,05)$ соответственно. Включение же в рацион пробиотика и антибиотика не выявило достоверных различий по сравнению с контролем в течение всего эксперимента.

Таким образом, литературные данные о положительном влиянии фитобиотиков на продуктивность животных $[4,6,12]$ подтверждаются и нашими исследованиями. Кроме того, известно, что экстракты растений, содержащие танины в малых концентрациях способны проявлять антибактериальную активность, снижая таким образом нагрузку на микробиоту организма и тем самым положительно влияя на рост и развитие животных [9, 10, 13, 14].

Нами был проведен химический анализ гомогената мышечной и костной тканей для определения их качественного состава (табл. 2). В опытных группах зафиксировано снижение жира по сравнению с контролем: в I - на 0,8 \%, во II - на $0,7 \%$, в III - на $0,4 \%$, в IV - на $0,3 \%$ и в V - на $1,18 \%$. Следует отметить, что в группе с добавлением в рацион экстракта Quercus cortex в концентрации 2 мг/кг корма содержание протеина увеличивалось на $0,8 \%$.

Заключение. Полученные результаты показывают перспективность использования растительных экстрактов (фитобиотиков), в частности Quercus cortex, в качестве кормовых добавок и заменителей антибиотиков. Существует возможность для создания на основе полученных экспериментальных данных препаратов новейшего поколения, применяемых в кормлении рыб.

Исследования выполнены за счет средств Облгранта Правительства Оренбургской области (Соглашение № 34 от 14.08.2019 г.)

\section{СПИСОК ЛИТЕРАТУРЫ}

1. Влияние аспарагинатов на продуктивность карпа при выращивании в садках / П.А. Грищенко [и др.] // Зоотехния. - 2010. - № 12. - С. 13-14.

2. Значение, теория и практика использования гуминовых кислот в животноводстве / А.А. Васильев [и др.] // Аграрный научный журнал. - 2018. - № 1. C. 3-6.

3. Использование пробиотиков и растительных экстрактов для улучшения продуктивности жвачных животных (обзор) / Г.К. Дускаев [и др.] // Живот- новодство и кормопроизводство. - 2019. - Т. 102. № 1. - С. 136-148.

4. Казачкова Н.М. Использование природных антибиотиков в рационе сельскохозяйственных животных и птицы // Инновационные технологии в образовании и науке: материалы Междунар. науч.-практ. конф. - Чебоксары, 2017. - С. 14-16.

5. Карасев А.А., Подуубная И.В., Васильев А.А. Эффективность применения в кормлении двухлеток карпа повышенной дозы йода в условиях садкового выращивания // Аграрный научный журнал. - 2015. - № 10. C. $8-10$.

6. Abreu A.C., McBain A.J., Simoes M. Plants as sources of new antimicrobials and resistance- modifying agents // Natural Product Reports, 2012. -Vol. 29 (9), P. 1007-1021.

7. Defoirdt T., Boon N., Bossier P., Verstraete W. Disruption of bacterial quorum sensing: An unexplored strategy to fight infections in aquaculture // Aquaculture, 2004, Vol. 240, P. 69-88.

8. Duskaev G.K., Deryabin D.G., Karimov I.F., Kosyan D.B., Notova S.V. Assessment of (In vitro) toxicity of quorum-sensing inhibitor molecules of Quercus cortex // Journal of Pharmaceutical Sciences and Research, 2018, T. 10, No. 1, P. 91-95.

9. Hashemi S.R., Davoodi H. Phytogenics as new class of feed additive in poultry industry // Journal of Animal and Veterinary Advances, 2010, Vol. 9 (17), P. 2295-2304.

10. Hashemi S.R., Davoodi H. Herbal plants and their derivatives as growth and health promoters in animal nutrition // Veterinary Research Communications, 2011, Vol. 35 (3), P. 169-180.

11. Koh K.H., Tham F.Y. Screening of traditional Chinese medical plants for quorum-sensing inhibitors activity // Journal of Microbiology, Immunology and Infection, 2011, Vol. 44, P. 144-148.

12. Schiavone A., Guo K., Tassone S., Gasco L., Hernandez E., Denti R., Zaccarato I. Effects of a natural extract of chestnut wood on digestibility, performance traits, and nitrogen balance of broiler chicks // Poultry Science, 2008, Vol. 87(3), P. 521-527.

13. Simoes M., Bennett R.N., Rosa E.A. Understanding antimicrobial activities of phytochemicals against multidrug resistant bacteria and biofilms // Natural Product Reports, 2009, Vol. 26 (6), P. 746-757.

14. Yang C., Chowdhury M.A., Huo Y., Gong J. Phytogenic compounds as alternatives to in-feed antibiotics: potentials and challenges in application // Pathogens, 2015, Vol. 4 (1), P. 137-156.

Мирошникова Елена Петровна, $\partial-p$ биол. наук, проф., зав. кафедрой «Биотехнологии животного сырья и аквакультура», Оренбургский государственный университет. Россия.

Аринжанов Азамат Ерсаинович, канд. с.-х. наук, доцент кафедры «Биотехнологии животного сы-

Химический состав гомогената мышечной и костной тканей карпа, \%

\begin{tabular}{|l|c|c|c|c|}
\hline \multicolumn{1}{|c|}{ Группа } & Влага & Жир & Протеин & Зола \\
\hline Контроль & $73,0 \pm 0,6$ & $10,9 \pm 0,81$ & $12,9 \pm 0,6$ & $3,2 \pm 0,8$ \\
\hline I & $74,1 \pm 1,0$ & $10,1 \pm 1,16$ & $11,9 \pm 0,1$ & $3,9 \pm 0,2$ \\
\hline II & $73,9 \pm 0,8$ & $10,2 \pm 0,96$ & $13,7 \pm 0,1$ & $2,2 \pm 0,2$ \\
\hline III & $74,2 \pm 1,1$ & $10,5 \pm 1,40$ & $13,1 \pm 0,1$ & $2,1 \pm 0,4$ \\
\hline IV & $74,1 \pm 1,2$ & $10,6 \pm 1,41$ & $13,0 \pm 0,4$ & $2,3 \pm 0,1$ \\
\hline V & $75,0 \pm 0,7 *$ & $9,72 \pm 0,83$ & $12,8 \pm 0,5$ & $2,5 \pm 0,9$ \\
\hline
\end{tabular}


рья и аквакультуры», Оренбургский государственный университет. Россия.

Килякова Юлия Владимировна, канд. биол. наук, доцент кафедры «Биотехнологии животного сырья и аквакультуры», Оренбургский государственный университет. Россия.

Дускаев Галимжан Калиханович, $\partial-p$ биол. наук, зав. отделом кормления сельскохозяйственных животных и технологии кормов им. С.Г. Леушина,
Федеральный научный иентр биологических систем и агротехнологий РАН. Россия.

Мирошникова Мария Сергеевна, магистр, Оренбургский государственный университет. Россия.

460018, г. Оренбург, просп. Победы, 13.

Тел.: (3532) 37-24-66.

Ключевые слова: растительные экстракты; фитобиотики; кормление рыб; карп; кора дуба.

\title{
EFFECTS OF QUERCUS CORTEX EXTRACT ON THE GROWTH AND DEVELOP-MENT OF CARP
}

Miroshnikova Elena Petrovna, Doctor of Biological Sciences, Professor of the chair "Biotechnology of Foodstuffs from Animals and Aquaculture”, Orenburg State University. Russia.

Arinzhanov Azamat Ersainovich, Candidate of Agricultural Sciences, Associate Profes-sor of the chair "Biotechnology of Foodstuffs from Animals and Aquaculture", Orenburg State University. Russia.

Kilyakova Yuliya Vladimirovna, Candidate of Biological Sciences, Associate Professor of the chair "Biotechnology of Foodstuffs from Animals and Aquaculture", Orenburg State University. Russia.

Duskaev Galimzhan Kalihanovich, Doctor of Biological Sciences, Federal Research Centre of Biological Systems and Agrotechnologies RAS, Federal Agency of Scientific Organizations. Russia.

Miroshnikova Maria Sergeevna, Magistrandt, Orenburg
State University. Russia.

Keywords: plant extracts; phytobiotics; fish feeding; carp; Quercus cortex

Studies have been conducted to determine the effect of feeding Quercus cortex extract in different dosages on the growth and development of carp in comparison with probiotics (Bi-fidobacterium longum) and antibiotics (ciprofloxacin hydrochloride). The studies found an increase in fish growth due to the introduction in the diet of Quercus cortex extracts concen-tration 1 and $2 \mathrm{mg} / \mathrm{kg}$ feed of 7,9\% and $10,7 \%(P<0,05)$, respectively. The inclusion of pro-biotic and antibiotic in the diet showed no significant differences compared to the control group.

\section{ЭКОЛОГИЧЕСКАЯ КОНЦЕПЦИЯ ФУНКЦИОНИРОВАНИЯ ПАРАЗИТАРНОЙ СИСТЕМЫ ПРИ ГИПОДЕРМАТОЗЕ КРУПНОГО РОГАТОГО СКОТА}

\author{
ТОЛОКОННИКОВ Василий Петрович, Ставропольский государственный аграрный университет \\ МАРЧЕНКО Вячеслав Вячеславович, ФГБУ «Ставропольская межобластная ветеринарная \\ лаборатория»
}

ВИКУЛОВА Людмила Сергеевна, ФГБНУ «ВНИИ ветеринарной санитарии, гигиены и экологии» ЧЕПЕЛЕВА Ольга Дмитриевна, Ставропольский государственный аграрный университет СоКОЛОВА Виктория Сергеевна, Ставропольский государственный аграрный университет

Показано, что возбудителями гиподерматоза крупного рогатого скота являются обыкновенный подкожный овод (строка) Нуродеrma bovis De Geer и южный подкожный овод (пищеводник) Нуродегта lineatum De Villers. Приведены данные о повсеместном распространении гиподерматоза в сельскохозяйственных зонах Ставропольского края. Установлено, ито гиподерматоз у крупного рогатого скота чаще регистрируют при пастбищном, чем при стойлово-выгульном содержании. Экстенсивность инвазии у животных, содержащихся в хозяйствах разных форм собственности, составляет 15,4-42,5 \%, интенсивность варьирует в пределах 18,5-29,5 экз./гол. Выявлено, ито активность кожных оводов в биоиенозе в течение суток и весенне-летнего периода регламентируется условиями окружающей среды. Численность популяиий оводов в Ставропольском крае демонстрируется определенным видовым соотношением: Hуродеrma bovis De Geer - 64,7 \%, Hуроderma lineatum De Villers - 33,7 \%. Изучены факторы регулящии численности популящий $\mathrm{H}$. bоvis и H. lineatum.

Введение. Скотоводство как ведущая отрасль животноводства Российской Федерации - основной поставщик молока и производитель мяса, кожевенного сырья, эндокринных препаратов и других ценных продуктов, получаемых при убое крупного рогатого скота [2]. Заразные болезни, к числу которых относится и гиподерматоз крупного рогатого скота, являются сдерживающим фактором успешного развития животноводства. Экономический ущерб при гиподерматозе круп- ного рогатого скота складывается из снижения привесов и удоев. В течение одного года от коровы, пораженной личинками кожного овода, недополучают 80-200 л молока (4,5 \% годового удоя), потеря живой массы у одного инвазированного животного достигает 13-18 кг [5, 13, 15].

В научной литературе отражены результаты исследований биологии, популяционной экологии, фенологии кожных оводов [3, 4, 6, 9], распространения гиподерматоза, патогенеза, эконо- 